\title{
The Impact Of Application Of Value Clarification Technique (VCT) Towards Ecoliteracy And Critical Thinking Skill Student Of Social Science In Primary School
}

\author{
Dadang Iskandar1),Deasy Rahmawati2),Acep Roni Hamdani ${ }^{3)}$ \\ 1,3)Pasundan University, Bandung, Indonesia \\ E-mail : ${ }_{1 \text { dang isk@yahoo.com }}$ \\ E-Mail:3acepronihamdani@unpas.ac.id \\ 2)Langlangbuna University, Bandung, Indonesia \\ E-Mail : :2 derafatri 14@yahoo.co.id
}

\begin{abstract}
.
The purpose of this study was to determine the effect of the application of Value Clarification Technique (VCT) to ecoliteracy and critical thinking skills of elementary school students in learning Social Science. The method used in this study is a quasi experimental design with non-equivalent control group design, using the two study groups. Subjects in this study were students of class IVSDN Cijerah Indah, Bandung Kulon District Bandung City. The experimental group was given the treatment of learning Value Clarification Technique (VCT) and the control group was given conventional learning. The results showed that in general there is a difference between learners ecoliteracy experimental class and control class and critical thinking skills among learners experimental class and control class after each class has been getting treatment that has been set.
\end{abstract}

Keywords: value clarification technique (VCT), critical thinking skill, ecoliteracy

\section{INTRODUCTION}

Human life on earth is not alone, but to live with other creatures, ie plants, animals and micro organisms (Cliff \& Grand, 1999). All other living things it is not just friends that live together in a neutral or passive toward people (Munson, Lauterbach, Newman, \& Resnick, 2010). The space occupied by a living thing along with a living and not live called the environment (Soemarwoto, 1997). Humans and other living beings occupy a certain space where they overlap and influence each other (Frith \& Frith, 2010). These resources not only to be used only and forever will continue to be used, but also must do careful planning and management by considering a variety of issues related to sustainability (Mathieson, 1991)

Man must be able to coexist with other creatures around him, because humans are not the only elements in an environment that determine the state of an environment. According Soemarwoto (1997) the nature of the environment is determined by several things, namely: 1) the type and amount of each type of element of the living environment; 2) the relationship or interaction between elements in the environment; 3) conduct or condition of environmental elements; and 4) non-material factors, temperature, light and noise. So an 
environment will be good or bad depending on the quantity and quality of the elements that exist in the environment and quality of interaction. Of the various elements in the environment, the human element is the most influential on other elements. Everyday human life can never be separated from the environment (Iskandar, 2001). This happens because human beings are given intellect and instinct to be able to manage the environment so that human beings have a more active role than other creatures, according Odum terms mentioned (in Iskandar, 2001) that human beings can be regarded as the controlling program ecosystems.

The interrelationship between humans and the surrounding environment (biophysical systems) or ecosystem is influenced by its culture, so that the cultural factor is very important for people to make the process of adaptation to the environment (Ingold in Iskandar, 2001). In accordance with the opinion of Soemarwoto (1997) that human beings have great adaptability, both biologically and culturally. Humans grow and develop in society by adjusting to the environment, the human ability not only influenced but also capable of providing remarkable influence on the environment (Mathieson, 1991). Mulyadi (2004) states that humans have culture, social institutions, knowledge and technology that is growing. This relationship certainly must be nurtured properly in order to create harmony among the various elements in the environment so the expectations on the sustainability of life for the generations really an issue that can be realized.

In this globalization era, along with the development of science and technology human life is growing in various aspects, including social and cultural life (Jensen, Arnett \& McKenzie, 2011). These changes not only have a positive impact but also adversely affect the surrounding environment and the various elements that are in it. Mulyadi (2014) states that the environmental experts the world meeting in Ratvich (Sweden) in 1982, identified 10 environmental problems on various scope recognized by almost all countries, among others: 1 ) the reduction of clean water for various needs of the population, due to disruption of the cycle hydrological and water resources and management is not appropriate in the watershed; 2) the extent of degraded soils due to declining soil stability, and the transfer function of agricultural land into non-agricultural, and declining soil due to erosion of fertile soil layer; 3) reduction of tropical land area is estimated globally; 4) memunahnya genetic diversity is also associated with decline in tropical forest cover; 5) the destruction of marine aquatic ecosystems, due to the removal of marine products that exceed the carrying capacity of ecosystems, and habitats for coastal and littoral regions, as well as the pollution of sea water; 6) climate warming of the earth due to the depletion of the ozone layer and the increasing levels of $\mathrm{CO}_{2} ; 7$ ) the increasing threat of $\mathrm{B} 3$ waste; 8) the increasing threat of acid rain due to contamination of $\mathrm{SO}_{2}$ and $\mathrm{NO}_{2}$ resulting from the burning of oil and gas and forest fire; 9) the threat of pathogens in domestic waste as well as aquatic vector; and 10) the still high rate of population growth and urbanization.

The environmental problems we have to deal with serious, because it concerns our survival on this earth (Anderson, Burnham, \& White, 1985). The above description clearly states that humans have a very big role for the sustainability and environmental sustainability in the vicinity. Humans are intelligent and have a good knowledge and thinking skills will certainly be able to manage the environment and 
natural surroundings wisely so that it can provide a great benefit for the man himself (McGuinness, 1999). This is consistent with the statement of the World Commission on Environment and Development (WCED) in 1984 in Stockholm Sweden in the program "Sustainable development" or "Sustainable Development" (Surtikanti, 2011) which states unequivocally that: "man in principle have the ability to make sustainable development so as to guarantee the fulfillment of human needs of today without compromising the right of future generations to meet their needs for natural resources".

In realizing this sustainable development, should start from growing the awareness on human beings themselves, because it relates to the behavior of everyday human life (McGuinness, 1999). The literature on environmental awareness is outlined very clearly by an educator from the American who works at the Center for Ecoliteracy in Berkeley, California, and focus on environmental education disciplines, namely David W. Orr and physicist Fritjof Capra in the 1990s. They both bring new value in education, the value is considered to be "the welfare of the earth" (Juris, 2012). According to Capra (2005), one of the solutions to overcome the crisis and catastrophic global environment it is to build a human society that is sustainable based on what he describes as the ecological literacy, ie our ability to understand the organizing principles that apply to all living systems and use them as a guide in creating sustainable societies. Environmental awareness in schools is a miniature of the wider society in which there is interaction between living things with their environment including subsystems that make up a life. This awareness can be nurtured through organized learning in school (Thellufsen, Rajabifard, Enemark, \& Williamson, 2009).

Process interactions are formed in schools through education or learning is expected to give birth to a human or human-educated learners who have concern and awareness of the environment (Inglis, 2005). Resolving environmental problems that occur in the school became one of our concern for environmental problems that occur in the world. This ecological literacy learning focus emphasizes the understanding of the principles of the organization of ecosystems and their potential application to understand how to build a sustainable human society (Cho \& Patten, 2013). By understanding ecoliteracy will change the perception of the need to protect the ecosystem is not just a belief held by a person in caring for the environment, but is a necessity in an effort to survive over time (Csikszentmihalyi \& Figurski, 1982).

Ecoliteracy is to be instilled in everyone, without exception of children. This ecoliteracy be instilled from an early age, in order to grow and develop into a good lifestyle, so that the activities of protecting the environment becomes an awareness of sustainability that can save us from generation to generation (Roeser \& Peck, 2009). The family as a child's first environmental education center should be a primary, because in a family environment first of all children get the education, guidance, care, habituation and training. Schools as the successor of sustainability education in the family is more formal, hierarchical and have a curriculum as a plan of education and teaching, there are teachers more professional as well as infrastructure and education facilities can support all educational processes that occur in it (Krnel \& Naglic, 2009). 
Education as an effort to humanize human beings should be able to be used as a small laboratory students to develop awareness, behavior, knowledge and skills of students in a nurturing environment. Starting from the smallest neighborhood students that families, schools up to the community in which students interact with the wider environment (Sandberg \& Reschly, 2011).

The education process is always happening in an environment, the physical environment, social, intellectual, and values ... physical .Lingkungan consists of the natural environment and the built environment ... social .Lingkungan an interaction between the human environment, relationshSocial Science between educators and students and parents people involved in education ... .Lingkungan intellectual interaction is the climatic conditions and around which encourage and support the development of thinking skills... .Lingkungan value of a life order value, good social values, economic, social, political, aesthetic, ethical and religious values espoused in a region or a specific kelomopok (Sukmadinata, 2009).

Through a process of education that has been mentioned above, the education helps development potential, abilities and personal characteristics of students through various forms of administration consciously. In the implementation of an education have a goal to be achieved, the goal of National Education of Indonesia as stated in Law No. 20 of 2003 on National Education System Chapter II Article 3 that aims at developing students' potential to become a man of faith and fear of God Almighty, noble, healthy, knowledgeable, skilled, creative, independent, and become citizens of a democratic and to be responsible. Then lowered into educational purposes at school level, in this case the elementary school educational purposes listed in the Indonesian Government Regulation No. 19 of 2005 on National Education Standards Article 26, paragraph 1. Primary education aims to lay the basis of intelligence, knowledge, personality, character, skills to live independently, to follow further education(Mursidi, 2015).

Very clearly mentioned in the educational objectives of education both nationally and primary school education that education is not only to provide a stock of knowledge only to students, but other aspects, too, is the target to be built in the implementation of an education, the attitude and skills. These objectives could involve students' own interests, the interests of society and the demands of jobs or all three are students, the community and the work at once. The education process directed at increasing mastery of the knowledge, abilities, skills, development of attitudes and values in the context of the establishment and development of the student (Sukmadinata, 2009).

In fact, the purpose of education is often limited to the acquisition of knowledge, skills and abilities alone, while the development of attitudes and values are often completely ignored. Though this is the attitudes and values that determine how a person can use the knowledge, skills and abilities he had in things that are right and positive (Aminrad, Zarina, Sayed Zakariya, Hadi, and Sakari, 2013). Similarly to how the students were able to have awareness of the environment that lead to sustainability is to save the earth. However, efforts to build a sustainable society can not succeed unless future generations want to learn how to cooperate with the 
natural systems to their mutual benefit (Amin, Mahadi, Ibrahim Yaacob, \& Nasir, 2012).

Many students know the result of littering, he was also unable to name the behavior that should be skilled in taking out the trash and dispose of waste in place (Steffen et al., 2015).But often they are indifferent and do not feel guilty when storing waste in places that are not supposed to be, this is where the lack of development of attitudes and values in students. Therefore, it is important planting of attitudes and values in students from elementary, because, in principle, children at primary school age are at a stage of psychological attitude formation. Marzano and Bruner (in Kemendikbud, 2014) that the elementary realm of attitude or demeanor should get more servings or more dominant introduced, taught or exemplified in the students, followed by the realm of skill, and the realm of knowledge that is less taught to elementary students(Ifit Novita Sari, 2015),

All subjects were there and studied, either integrated or partially (separate) basically is not only concerned with the development aspects of knowledge or the students' cognitive, but also related to the development of attitudes and values and skills (Parks \& Guay, 2009). The link between the value of the education is indeed very closely. When we speak of truth, goodness, honesty, decency, beauty, or responsibility, though unfinished if not up on how the actions of education needs to be done so that the values that are owned by someone (Pratto, Sidanius, Stallworth, \& Malle, 1994). It strikes the human values education to be more humane to have the primary mission is to realize the value of life to the students, both to achieve the educational goals of short-term and long-term (Mulyana, 2011).

Planting a good mental attitude or through teaching Social Science can not be separated from teaching values and systems of values prevailing in the society with the aim to foster and develop a good mental attitude (Abzari, Ghassemi, \& Vosta, 2014). Educational value according Mulyana (2011) covers all aspects as teaching or guidance to the students to realize the values of truth, goodness, and beauty, through the process of consideration of the proper value and habituation to act consistently. With terbinanya values are good and focused on them, the mental attitude will be positive to stimuli from the environment, so that the behavior and actions do not deviate from the noble values. Thus the behavior and actions are always guided by responsibility towards themselves and towards their environment.

In Indonesia, the value of education is taught exclusively through Religious Education, Citizenship Education and Social Sciences (Social Science) as a separate subject or partially. In accordance with the principle of the Learning Social Science according to NCSS (1994): a) social studies teaching and learning are powerful when they are meaningful, b) social studies teaching and learning are powerful when they are integrative, c) social studies teaching and learning are powerful when they are value-based, d) social studies teaching and learning are powerful when they are challenging, and e) social studies teaching and learning are powerful when they are active.

Mulyana (2011) mentions that the development of value in Social Science always involves three distinct stages, the first stage revolves around the introduction of the facts of the environment, the second stage is the stage of the formation of concepts, 
and the third stage is the stage of consideration of the integrated value. Therefore, Social Science is a subject that has a major concern in helping students become good citizens. This is consistent with the primary purpose of Social Science by NCSS (1994) "to help young people develop the ability to a make informed and reasoned decisions for the public good as citizens of a culturally diverse, democratic society in an interdependent world." This means that Social Science aims to help young people develop the ability to make an intelligent decision and reason for the public good as citizens of a pluralistic society and a democratic culture in a world of mutual dependency. In this case, Social Science should be able to help students develop the knowledge, understanding, skills, and values that are essential for citizens in a democratic nation.

Social Science is not sufficiently studied revolves around the concept, identify a number of phenomena, it is necessary sharpness of an analysis of the value in a number of social issues that arise today. Values are integrated in social studies learning can be an intrinsic value such as objectivity, rationality, and scientific honesty or can be basic moral values like concern for others, empathy and other social good (Mulyana, 2004). The importance of the Social Science evident when children will make decisions or solve problems. The ability to make decisions should be developed and practiced in schools, particularly through the Social Science. Savage and Armstrong (in Effendi, 2009) stated that the consideration for making a decision is made as a result of the interplay between evidence (evidence) and personal values.

Naylor and Diem (in Effendi, 2009) states that the primary purpose of education value in the program Social Science must have two aspects: to provide ample opportunities for students to identify the attitudes, beliefs, and values BAUK private or public, and to familiarize them with the process of testing various attitudes, beliefs and values. In accordance with the primary goal of education in the Social Science value, then the value of learning from some choice in the corresponding Social Science is through learning by Value Clarification Technique (VCT). Raths et al. (1978) suggested that the Value Clarification Technique (VCT) is one of the values or moral education approach that does not directly focus on helping students clarify values or clarify their own values. Raths, et al (in Komalasari, 2011) states there are seven stages in the process of assessing the Value Clarification Technique (VCT), which are summarized as follows: a) to choose freely; b) selecting from a variety of alternatives; c) choosing after holding a consideration of the various consequences; d) feel happy or happy with her choice; e) to admit his choice in public; f) act in accordance with his choice; and g) act repeatedly as a pattern of behavior in life.

Based on the above, the authors are interested in doing further research with the title "The Effect of Implementation of Value Clarification Technique (VCT) to the attitude Ecoliteracy and Critical Thinking Skills Elementary students in the Learning Social Science". This study is expected to be a positive impact on the success of the learning activities in social studies, especially in the learning value that is often overlooked in school. Indeed the value of learning by using Value Clarification Technique (VCT) This not only helps the students to re-examine his personal values, 
but also can train students' critical thinking skills to be able to develop values ecolitaracy students in himself through clarification and self-awareness.

\section{METHOD}

The research design used in this study is a quasi-experimental design with Nonequivalent Control Group Design. In this design, the experimental group (A) and the control group (B) were selected without random placement procedure. In both groups performed equally pretest and posttest. Only the experimental group who were given treatment (Creswell, 2012).

\section{ecoliteracy}

Based on t-test results on the score obtained results ecoliteracysig (2-tailed) = 0.000 , which means value sig (2-tailed) $0.000<0.05$. Then the hypothesis $\mathrm{H}_{0}$ is rejected and $\mathrm{H}$ laccepted, so it can be stated that there is a difference ecoliteracy experimental class control class. This proves that learning VCT (Value Clarification Technique) to give effect to ecoliteracystudents. In addition ecoliteracy gain test results showed the experimental class of $\mathrm{n}$ gain of 0.21 with the interpretation that the n-gain the experimental class is included in the criteria of "Low". While the test results ecoliteracy gain on gain control class $\mathrm{n}$ gain of 0.09 . Then the $n$-gain the control class was included in the criteria of "Low". Based on the comparison results of $n$-Gain experimental class and control class, we can conclude that ecoliteracy experimental class and control class there is an increase, but not too big. When compared to the increase, the experimental class had greater increases $12 \%$ greater than the increase in the control class. In addition to the results of the data obtained, it should also be submitted descriptions of treatment and matters arising in connection with ecoliteracy. In the implementation of student learning is done ecoliteracy appear when presented pictures of the garbage and the environment. When given questions with regard to the learning of Value Clarification techique (VCT), seen the enthusiasm of the students in conveying its value.Students have a positive argument when presented pictures of garbage that are in the wrong place, and they were able to deliver a solution that is in accordance with the values contained in ecoliteracy.

When presented the wrong image of waste management, ie without separation and segregation. Students can give the opinion that, when this happens in the environment around them is the same thing as in the picture. They argue that good waste management means it can not be done by one party alone, but must be done by all parties with full awareness.From some of the findings and research results, then we can see that the results of calculations of data ecoliteracy accordance with 
the findings in the form of changes ecoliteracy students when learning Value Clarification Technique treatment (VCT) is given.

\section{Critical Thinking Skills}

Based on the results uji- Mann Whitney $U$ on critical thinking skills scores obtained results sig (2-tailed) $=0.000$, which means value sig (2-tailed) $0.000<0.05$. Then the hypothesis $\mathrm{H}_{0}$ is rejected and $\mathrm{H}_{1}$ accepted, so it can be stated that there is a difference in the critical thinking skills of experimental class control class. This proves that learning VCT (Value Clarification Technique) give effect to the critical thinking skills students. In addition the test results gain critical thinking skills of classroom experiments show $\mathrm{n}$ gain of 0.36 with the interpretation that the $\mathrm{n}$ - gain the experimental class is included in the criteria of "Medium". While the test results on the class gain attitude control ecoliteracy obtain $\mathrm{N}$-gain of 0.14 .Then the $n$-gain the control class is included in the criteria of "Low".

Based on the comparison of the $N$-Gain experimental class and control class, we can conclude that the critical thinking skills experimental class is better than the control class. This shows that VCT (value Clarification Technique) can stimulate students' critical thinking skills, because the VCT students learning students can be helped to assess their own feelings and actions. In this lesson students are required to be able to have their own values or attitudes appropriate to the assessment and argument alone. Whatever values and attitudes which they choose must have reasons and considerations that can be for accounted.

\section{RESULTS AND DISCUSSION}

In the discussion of this study, will be described on the discussion of the analysis of research that has been done then linked to the theories that support the research. The discussion in this study is the learning effect of Value Clarification Technique (VCT) to ecoliteracy and critical thinking skills of elementary school students in social studies learning.

\section{The influence VCT (Value Clarification Technique) against Ecoliteracy student}

Based on the analysis of research that has been done, the results obtained average pretest ecoliteracy students in the experimental class that is equal to 79.86 with an average of 88.97 posttest. While the average value postetest ecoliteracy students in the control class that is equal to 71.89 with an average of 76.19 posttest. From the results of the pretest and posttest we can observe that the 
experimental class and the control class has increased ecoliteracy, which amounted to 9.11 at 4.31 in the experimental class and control class. Average increase in the experimental class is greater than the control class. To determine the criteria for the increase and the difference it can be observed by looking at the test results gain. The experimental class score of $\mathrm{N}$-gain is equal to 0.21 and when seen in the criteria gain these results demonstrate the criteria of "low". In the control group obtained a score of $\mathrm{n}$ gain of 0.09 , a low value indicates criteria anyway. This proves that learning by using VCT(Value Clarification Technique) can improve student ecoliteracy.

Ecoliteracy proof that there is a difference between the experimental class that implements VCT (Value Clarification Technique) the control class that implements conventional learning can be seen on t-test results. This test is performed for the normality test turns all the data were normally distributed and homogeneous. Before giving posttest to determine the final test results, conducted in advance of initial tests (pretest). Having obtained the results of initial tests and then in the test, it turns on pretest scores experimental class and control class there is a difference, however small. This shows that the pretest results are less good, because according Sugiyono (2008) that the pretest good results when the value of the experimental group was not significantly different from the control group. After the t-test was performed on the data posttest between the experimental class control class. The data is interpreted that there is a difference between experimental class control class. In the t-test results showed sig (2-tailed) $=0.000$, which means value sig (2-tailed) $0.000<0.05$. Then the hypothesis $\mathrm{H}_{0}$ is rejected $\mathrm{H}_{1}$ accepted. It is proved that there are significant differences regarding ecoliteracy among students in the experimental class that implements VCT (Value Clarification Technique) the control class that implements conventional learning.

Based on the description of the above results, it is consistent with the theory mentioned by Adisusilo (2012), about the purpose of VCT (Value Clarification Technique) that VCT helps students so that they use jointly the ability to think rationally and emotional awareness, to understand the feelings, values, attitudes and behavior patterns of their own and finally compelled to live it. This is in accordance with what is mentioned by Hardin (in Orr, 1992), that "ecological literacy is the ability to ask" what then? ". The purpose of this description that through learning the VCT students honed thinking skills to be able to understand the value in itself in order to have an attitude and solutions for environmental 
problems. VCT and ecoliteracy is reflective thinking process, so that if VCT is done in the classroom, it will help clarify the existing ecoliteracy back in her students.

Ecoliteracy inseparable from the cultivation of values, as expressed Callenbach (Stone, M. and Barlow, Z, 2005) "at the center for ecoliteracy we believe that at their heart, the ecological problems we face are ploblem of values". The point is that every human being who lives in a neighborhood have a rule in behavior daily, in bertingkahlaku is certainly very concerned about the values that should-have for all that we do is based on the truth at a good value system. Then, according to Woolover (1988) Value Clarification is a process for examining personal values. Where students know that its value is affected by the surrounding environment. As the authors expect that through VCT learning, students are expected to terbina ecoliteracy- her well where the actual values ecoliteracy it has existed in students.

The test results showed the experimental class ecoliteracy gain of $\mathrm{N}$-gain of 0.21 with the interpretation that the $\mathrm{N}$-gain the experimental class is included in the criteria of "Low".While the test results on the class ecoliteracy gain control gain of $\mathrm{N}$ - gain of 0.09. Then N-gain the control class was included in the criteria of "Low". Based on the comparison of the $N$-Gain experimental class and control class, we can conclude that ecoliteracy experimental class and control class there is an increase, but not too big. Achievement of N-Gain is the experimental class is similar to the control class, and both are included in the low category. This happens can occur because of the implementation of VCT rudimentary. If the seven processes in VCT is not implemented yet actually produce real value of a person, as Adisusilo (2012) pointed out that: seven processes in VCT is seen as a criterion for determining whether something is a real value (true value) for the remarkable and innovative. If anything is missing, then it is not yet a real value, it is only the indicator value ( $a$ true value ).

In accordance with the opinion of Komalasari (2011) that the role of teachers in values clarification approach is to encourage students with questions relevant to develop students' skills in the process of judging. This factor can be one of the low acquisition $\mathrm{N}$-Gain, the preparation of a more mature should really be done in this VCT learning.

\section{The influence VCT ( Value Clarification Technique) Critical Thinking Skills Students}

In the study not only measured the effect of learning VCT (Value Clarification Technique) to AA ecoliteracyalone, but also measured the effect of learning VCT (Value Clarification Technique) to the students' critical thinking skills. The 
results of data processing and analysis the average pretest critical thinking skills of students in the experimental class is 59.72 with an average posttest at 73.69 . While the average value posttest critical thinking skills of students in the control class that is equal to 52.00 with an average posttest at 61.97 . From the results of the pretest and posttest that we can observe that the experimental class and control class increased critical thinking skills, which amounted to 13.97 in the experimental class and the control class 9.97. Average increase in the experimental class is greater than the control class.

To determine the criteria for the increase and the difference it can be observed by looking at the test results gain. The experimental class score of $\mathrm{N}$-gain is equal to 0.36 and when seen in the criteria gain these results demonstrate the criteria of "being". In the control group obtained a score of $\mathrm{N}$ gain of 0.14 value indicates the criteria of "low". This proves that learning by using VCT (Value Clarification Technique) can improve students' critical thinking skills are better than conventional learning.

Proof that there is a difference between the critical thinking skills of experim(Sari \& Wajdi, 2017)ental classes that implement VCT ( Value Clarification Technique ) with a control class that implements conventional learning can be seen in the results uji- Mann Whitney. Uji- Mann Whitney was done because the normality test turned out to be one of the data, ie data posttest that distribution is not normal. Before giving posttest to determine the final test results, the test of critical thinking skills to do well early tests ( pretest) beforehand). Having obtained the results of initial tests and then in the test, it turns on the score pretest experimental class and control class there is a difference, it indicates that there has been no difference in the beginning of students' critical thinking skills. Once it is done uji-Mann Whitney on the data posttest between the experimental class control class. The data is interpreted that there is a difference between experimental class control class. In the t-test results show the value sig (2-tailed) $=0.000$, which means value sig (2-tailed) 0.000 $<0.05$. Then the hypothesis $\mathrm{H}_{0}$ is rejected $\mathrm{H}_{1}$ accepted. It is proved that there are significant differences regarding critical thinking skills among students in the experimental class that implements VCT (Value Clarification Technique) with a control class that implements conventional learning.

Differences in the level of critical thinking skills of students using the experimental class learning VCT (Value Clarification Technique) with grade control using conventional learning can be caused by several factors. In essence, there is no model or technique that is bad or good, but what happens is the fitness model or learning 
techniques that are used with the objective to be achieved. In this study the theory presented in the previous chapter, has been proven in accordance with the hypothesis made prior to the research. The definition of critical thinking by Dewey is a process of "active" ( reflective thinking) and define it as the active consideration, and caution against the belief or knowledge that should form the grounds for and the further conclusion that leads to him. Based on the definition of VCT (Value Clarification Technique ) according Adisusilo (2011) is an educational approach in which the value of students are trained to find, select, analyze, decide, take a stand alone life values that will be fought. Seen the same activities occur in the VCT (Value Clarification Technique) and critical thinking. So learning VCT (Value Clarification Technique ) can facilitate the students hone their critical thinking skills.

The learning objectives learning VCT (Value Clarification Technique) assist students in practice the skills of thinking, as expressed by Adisusilo (2012), which helps the students so that they are able to use the jointly kemampun rational thinking and emotional awareness, to understand the feelings, values, attitudes, and behavior patterns of their own and eventually compelled to live it. This is evidenced by the test results gain critical thinking skills experimental class larger than the control class, which amounted to 0.36 with the interpretation that the $\mathrm{N}$-gain the experimental class is included in the criteria of "Medium". While the test results gain critical thinking skills in the classroom control gain of $\mathrm{N}$-gain of 0.14 and included in the criteria for "Low". In the implementation of learning VCT ( Value Clarification Technique) performed in this study, which when the teacher gives some social problem picture environment. Visible expression of very serious students pay attention to the images before they write the assessment of the rendered image. It is used as (entry bahaviour) students in learning VCT (Value Clarification Technique ). Student learning is so closely followed because of the VCT (Value Clarification Technique) which dutamakan is to develop the student's skills in the process of judging. In learning VCT (Value Clarification Technique) students are given the trust and not be pressed to answer as set by the teacher, so that they are so eager to show his personal assessment with confidence. In contrast to the control class is still in doubt because it is tied to the specified standard of truth.

\section{CONCLUSION}

Based on the research that has been described, then a number of conclusions that presents the interpretation and meaning of researchers on the analysis of research findings. As has been mentioned before that this study wanted to determine the 
effect of learning VCT (Value Clarification Technique) to ecoliteracy and critical thinking skills of students.

1. Learning the value of VCT (Value Clarification Technique) has an influence on ecoliteracy students. Conclusions can be drawn based on the results of the analysis of data shows that there is a significant difference in ecoliteracy students who use the learning VCT (Value Clarification Technique ) with ecoliteracy students who use conventional methods of learning. Ecoliteracy can be obtained through reflective thinking activities that can be developed in learning VCT (Value Clarification Technique ). Ecoliteracy needed to sustain all forms of life on this earth, so it takes awareness that comes from within students through values clarification and good behavior that already existed within the student.

2. Learning the value of VCT (Value Clarification Technique) has an influence on critical thinking skills of students . Learning VCT ( Value Clarification Technique) to train students to think and explore the values that exist in him to later clarified, so as to improve the critical thinking skills of students. After analyzing the data can be obtained that there are significant differences in the critical thinking skills of students who use the learning VCT (Value Clarification Technique) with the critical thinking skills of students who use conventional methods of learning. This can happen because the learning VCT (Value Clarification Technique) includes the steps of reflective thinking that is characteristic of critical thinking activities.

\section{RECOMMENDATION}

Based on the conclusions of this study, further put forward recommendations in order to improve the Social Sciences in Primary Schools, namely:

1. For maker policy, attitude ecoliteracy and k etrampilan critical thinking need to be developed at primary school children, both of which are a very important part of a child's cognitive development. Children from elementary school age need to be trained to express their ideas and their ideas, have a strong attitude and responsible. Earth increasingly frail, complete with less intact environment if allowed to continue without the correct action would be detrimental to the man himself and all life on this earth. If students do not have concern for the environment, it will have no trouble in his time later.

2. For the users of research results, namely teachers and researchers next need to use Learning VCT (Value Clarification Technique), in order to develop the 


\section{Edutec}

Journal of Education And Technology

2597-9221 (Online)

potential of the ability to think of children, teachers must be able to position itself as a facilitator and motivator of learning so that children can actualize themselves optimally, provides the opportunity for students to freely conduct excavations on the values he speaks. Furthermore this research in addition to the elementary school students really need to do research on educators or teachers in schools, in order to improve the quality of educators, besides da lam every activity in school g uru must give the example of how to behave and think critical properly so that children can imitate what is done by the teacher.

\section{REFERENCES}

Abzari, M., Ghassemi, R. A., \& Vosta, L. N. 2014. Analysing the Effect of Social Media on Brand Attitude and Purchase Intention: The Case of Iran Khodro Company. Procedia - Social and Behavioral Sciences, 143, 822-826. https://doi.org/10.1016/j.sbspro.2014.07.483

Adisusilo, S. 2011. Pembelajaran Nilai-Nilai Karakter: Konstruktivisme dan VCT Sebagai Inovasi Pendekatan Pembelajaran Afektif.Jakarta: PT. Rajagrafindo Persada.

Amin, L., Mahadi, Z., Ibrahim, R., Yaacob, M., \& Nasir, Z. 2012. The Effectiveness of the "Environment \&amp; Health" Course in Increasing Students' Awareness \&amp; Knowledge on Environmental Health Issues. Procedia - Social and Behavioral Sciences, 59(1998), 77-84. https://doi.org/10.1016/j.sbspro.2012.09.248

Aminrad, Z., Zarina, S., Sayed Zakariya, B., Hadi, A. S., \& Sakari, M. 2013. Relationship Between Awareness, Knowledge and Attitudes Towards Environmental Education Among Secondary School Students in Malaysia. World Applied Sciences Journal, 22(9), 1326-1333. https://doi.org/10.5829/idosi.wasj.2013.22.09.27.

Anderson, D. R., Burnham, K. P., \& White, G. C. 1985. Problems in Estimating AgeSpecific Survival Rates from Recovery Data of Birds Ringed as Young. The Journal of Animal Ecology, 54(1), 89. https://doi.org/10.2307/4622

Capra, F. 2002. Jaring-Jaring Kehidupan Visi Baru Epistemologi dan Kehidupan. Terjemahan oleh Saut Pasaribu. Yogyakarta: Fajar Pustaka Baru.

Cho, C. H., \& Patten, D. M. 2013. Green accounting: Reflections from a CSR and environmental disclosure perspective. Critical Perspectives on Accounting, 24(6), 443-447. https://doi.org/10.1016/i.cpa.2013.04.003

Cliff, D., \& Grand, S. 1999. The Creatures Global Digital Ecosystem. Artificial Life, 5(1), 77-93. https://doi.org/10.1162/106454699568683

Csikszentmihalyi, M., \& Figurski, T. J. 1982. Self-awareness and aversive experience in everyday life. Journal of Personality, 50(1), 15-19. https://doi.org/10.1111/j.1467-6494.1982.tb00742.x 
Creswell, J., W., (2012). Research design Pendekatan kualitatif, Kuantitatif dan Mixed; Cetakan ke 2, Yogyakarta: Pustaka Pelajar.

Effendi, R, dkk. (2009). Pengembangan Penidikan IPS SD. Direktorat Jenderal Pendidikan Tinggi Departemen Pendidikan Nasional.

Frith, U., \& Frith, C. (2010). The social brain: allowing humans to boldly go where no other species has been. Philosophical Transactions of the Royal Society of London. Series B, Biological Sciences, 365(1537), 165-76. https://doi.org/10.1098/rstb.2009.0160

Inglis, D. (2005). Culture and Everyday Life. Culture and Everyday Life. Routledge. https://doi.org/10.4324/9780203005200

Iskandar, J. 2001. ManusiaBudaya dan Lingkungan: Kajian Ekologi Manusia. Bandung: Humaniora Utama Press.

Jensen, L. A., Arnett, J. J., \& McKenzie, J. 2011. Globalization and Cultural Identity. In Handbook of Identity Theory and Research (Vol. 6, pp. 285-301). New York, NY: Springer New York. https://doi.org/10.1007/978-1-4419-7988-9_13

Juris, J. S. 2012. Reflections on \#0ccupy Everywhere: Social media, public space, and emerging logics of aggregation. American Ethnologist, 39(2), 259-279. https://doi.org/10.1111/j.1548-1425.2012.01362.x

Kemendikbud. 2014. Materi Pelatihan Guru Implementasi Kurikulum 2013. Jakarta

Komalasari, K. 2010. Pembelajaran kontekstual (konsep dan aplikasi). Bandung: Refika Aditama.

2011. Asesmen Teknik Non Tes dalam Perspektif BK Komprehensif. Jakarta: PT Indeks.

Krnel, D., \& Naglic, S. 2009. Environmental literacy comparison between eco-schools and ordinary schools in Slovenia. Science Education International, 20(1), 5-24.

Orr, D. W. 1992. Ecological Literacy Education and The Trantition to a Postmodern Worl. New York: State University of New York Press.

Mathieson, K. 1991. Predicting user intentions: Comparing the technology acceptance model with the theory of planned behavior. Information Systems Research, 2(3), 173-191. https://doi.org/10.1287/isre.2.3.173

McGuinness, C. 1999. From Thinking Skills To Thinking Classrooms. School of Psychology, Queens' University, Blefast, (April), 1-4.

Mulyadi, A. 2004. Pengetahuan Lingkungan. Bandung: Sarwayasa Press.

Mulyana, R. 2011. Mengartikulasikan Pendidikan Nilai. Bandung : Alfabeta.

Munson, S. A., Lauterbach, D., Newman, M. W., \& Resnick, P. (2010). Happier Together: Integrating a Wellness Application into a Social Network Site. In Lecture Notes in Computer Science (including subseries Lecture Notes in Artificial Intelligence and Lecture Notes in Bioinformatics) (Vol. 6137 LNCS, pp. 27-39). https://doi.org/10.1007/978-3-642-13226-1_5

NCSS. 1994. The curriculum standards for social studies; expectations of excellence. USA.

Parks, L., \& Guay, R. P. 2009. Personality, values, and motivation. Personality and Individual Differences, 47(7), 675-684. https://doi.org/10.1016/j.paid.2009.06.002

Pratto, F., Sidanius, J., Stallworth, L. M., \& Malle, B. F. 1994. Social dominance orientation: A personality variable predicting social and political attitudes. 
Journal of Personality and Social Psychology, 67(4), 741-763. https://doi.org/10.1037/0022-3514.67.4.741

Roeser, R. W., \& Peck, S. C. 2009. An Education in Awareness: Self, Motivation, and SelfRegulated Learning in Contemplative Perspective. Educational Psychologist, 44(2), 119-136. https://doi.org/10.1080/00461520902832376

Sandberg, K. L., \& Reschly, a. L. 2011. English Learners: Challenges in Assessment and the Promise of CurriculumBased Measurement. Remedial and Special Education, 32(2), 144-154. https://doi.org/10.1177/0741932510361260

Steffen, W., Richardson, K., Rockström, J., Cornell, S. E., Fetzer, I., Bennett, E. M., ... Sörlin, S.

Soemarwoto, 0. 2004. Ekologi Lingkungan Hidup dan Pembangunan. Jakarta: Djambatan.

Stone, M. K, and Barlow, Z 2005. Ecological Literacy Educating Our Children for a Sustainable World. San Francisco: Sierra Club Books.

Sugiyono. 2008. Metode Penelitian Pendidikan: Pendekatan Kuantitatif, Kualitatif, dan R\&D. Bandung: Alfabeta.

Surtikanti, H.K. 2011. Biologi Lingkungan.Bandung: Prisma Press Prodaktama.

Sukmadinata, Nana Syaodih. 2009. Metode Penelitian Pendidikan. Bandung: Kerjasama UI dan Remaja Rosdakarya.

Thellufsen, C., Rajabifard, A., Enemark, S., \& Williamson, I. 2009. Awareness as a foundation for developing effective spatial data infrastructures. Land Use Policy, 26(2), 254-261. https://doi.org/10.1016/j.landusepol.2008.03.002

2015. Sustainability. Planetary boundaries: guiding human development on a changing planet. Science (New York, N.Y.), 347(6223), 1259855. https://doi.org/10.1126/science.1259855 